Atıf İçin: Erdem K, Bilgi Kamaç M, 2021. Kanser Biyobelirteci Alfa-Fetoproteinin Elektrokimyasal Tayini İçin Tek Kullanımlık Etiketsiz Yeni AFP İmmünosensörünün Geliştirilmesi. Iğdır Üniversitesi Fen Bilimleri Enstitüsü Dergisi, 11(2): 1279-1292.

To Cite: Erdem K, Bilgi Kamaç M, 2021. Development of a New Disposable Label-free AFP Immunosensor for Electrochemical Detection of Cancer Biomarker Alpha-Fetoprotein. Journal of the Institute of Science and Technology, 11(2): 1279-1292.

\title{
Kanser Biyobelirteci Alfa-Fetoproteinin Elektrokimyasal Tayini İçin Tek Kullanımlık Etiketsiz Yeni AFP İmmünosensörünün
} Geliştirilmesi

\section{Kadir ERDEM ${ }^{1}$, Melike BİLGİ KAMAÇ ${ }^{*}$}

ÖZET: Bu araştırmada, bir kanser biyobelirteci olan alfa-fetoproteinin (AFP) elektrokimyasal tayini için tek kullanımlık yeni etiketsiz immünosensör geliştirilmiş ve insan kan serumu numunelerinde uygulaması gerçekleştirilmiştir. Çalışmada yüzey baskılı karbon elektrotlar (SPCE) ilk olarak indirgenmiş grafen oksit (RGO) ile modifiye edilmiş ardından elektropolimerizasyon tekniği uygulanarak elektrot yüzeyi polinötral kırmızı (PNR) ile kaplanmış, son olarak elektrodepozisyon metodu ile altın nanoparçacıklar (AuNP) yüzeyde oluşturulmuştur. SPCE/RGO/PNR/AuNP elektrodunun elektrokimyasal karakterizasyonu dönüşümlü voltametri (CV), diferansiyel puls voltametri (DPV) ve kare dalga voltametri (SWV) metotları kullanılarak yapılmıştır. SPCE/RGO/PNR/AuNP elektrotların yüzeyine Anti-AFP'nin immobilizasyonu 3merkaptopropiyonik asit (3-MPA) ve 1-etil-3-(3-dimetilamino-propil) karbodiimid/N-hidroksisüksinimid (EDC/NHS) kullanılarak kovalent bağlama yöntemi ile gerçekleştirilmiştir. Hazırlanan AFP immünosensörünün optimum çalışma parametreleri DPV ve SWV metotları ile belirlenmiştir. DPV ve SWV metotları ile belirlenen doğrusal tayin aralıkları 1-500 ng mL $\mathrm{mL}^{-1}$, tespit limitleri ise sırasıyla $0.79 \mathrm{ng} \mathrm{mL}^{-1} \mathrm{ve} 0.86 \mathrm{ng}$ $\mathrm{mL}^{-1}$ olarak belirlenmiştir. AFP immünosensörünün tekrarlanabilirliği $50 \mathrm{ng} \mathrm{mL}^{-1}$ AFP konsantrasyonu için test edilmiş ve bağıl standart sapma (R.S.D.) değerleri DPV ve SWV metotları için sırasıyla \%4.06 (n=10) ve \%3.68 (n=10) olarak hesaplanmıştır. Geliştirilen AFP immünosensörünün uygulama kararlılığ 60 gün boyunca, depolama kararlılı̆̆ ise 12 hafta depolama süresince voltametrik metotlarla incelenmiştir. Hazırlanan AFP immünosensörleri insan serumu örneklerine bilinen miktarda ilave edilen farklı konsantrasyonlardaki AFP'nin analizi için kullanılmış ve \%95'in üstünde geri kazanımlar elde edilmiştir.

Anahtar Kelimeler: Elektrokimyasal AFP immünosensörü, kanser biyobelirteci, indirgenmiş grafen oksit, polinötral kırmızı, altın nanopartikül, yüzey baskılı karbon elektrotlar

\section{Development of a New Disposable Label-free AFP Immunosensor for Electrochemical Detection of Cancer Biomarker Alpha-} Fetoprotein

\begin{abstract}
In this study, a new disposable label-free immunosensor was developed for the electrochemical determination of alpha-fetoprotein (AFP) that is a cancer biomarker and its application was performed on human blood serum samples. In the work, firstly the screen printed carbon electrodes (SPCE) were modified with reduced graphene oxide (RGO), then the electrode surface was coated with polyneutral red (PNR) by applying the electropolymerization technique and finally, gold nanoparticles (AuNP) were created by electrodeposition method on the surface. Electrochemical characterizations of the SPCE/RGO/PNR/AuNP electrode were performed using cyclic voltammetry (CV), differential pulse voltammetry (DPV), and square wave voltammetry (SWV) methods. Immobilization of Anti-AFP to the surface of SPCE/RGO/PNR/AuNP electrodes was carried out by a covalent binding method using 3-mercaptopropionic acid (3-MPA) and 1-ethyl-3-(3-dimethylaminopropyl)carbodiimide/N-hydroxysuccinimide (EDC/NHS). The optimum working parameters of the prepared AFP immunosensor were determined by DPV and SWV methods. It was calculated that the linear range was 1-500 $\mathrm{ng} \mathrm{mL}^{-1}$, the limit of detections was $0.79 \mathrm{ng} \mathrm{mL}^{-1}$, and $0.86 \mathrm{ng} \mathrm{mL}^{-}$ ${ }^{1}$, respectively. The reproducibility of the AFP immunosensor was tested for $50 \mathrm{ng} \mathrm{mL}^{-1}$ AFP concentration and relative standard deviation (R.S.D.) values were calculated as 4.06\% ( $\mathrm{n}=10)$ and 3.68\% $(\mathrm{n}=10)$ for DPV and SWV methods, respectively. The operation stability of the developed AFP immunosensor was examined by voltammetric methods for 60 days, and the storage stability for 12 weeks. The prepared AFP immunosensors were used for the analysis of different concentrations of AFP added to the human serum samples in a known amount and over $95 \%$ recoveries were obtained.
\end{abstract}

Keywords: Electrochemical AFP immunosensor, cancer biomarker, reduced graphene oxide, polyneutral red, gold nanoparticle, screen-printed carbon electrodes

\footnotetext{
${ }^{1}$ Kadir ERDEM (Orcid ID: 0000-0002-9146-0226), Melike BİLGİ KAMAÇ (Orcid ID: 0000-0002-3381-7522), Çankır1 Karatekin Üniversitesi, Fen Fakültesi, Kimya Bölümü, Çankırı, Türkiye

*Sorumlu Yazar/Corresponding Author: Melike BİLGİ KAMAÇ, e-mail: melikebilgikamac@gmail.com

Bu çalışma Kadir ERDEM'in Yüksek Lisans tezinden üretilmiştir. Makalede yer alan çalışmaların bir kısmı 8-11 Temmuz 2019 tarihlerinde Çanakkale'de düzenlenen “4th International Congress on Biosensor” de poster olarak sunulmuştur.
} 


\section{GíRiş}

Molekül ağırlığı yaklaşık $70 \mathrm{kDa}$ olan alfa-feto protein (AFP), 590 çeşit aminoasit içeren ve yaklaşı \%3.4 karbonhidrattan oluşan bir onkofetal glukoproteindir (Zhou ve ark., 2018). Karaciğer, testis ve hepetosellular kanserinde (HCC), vitellus kesesi ve diğer kötü huylu tümörlerde bulunur. HCC hastalarının kanında \% 75-80 oranında AFP bulunduğu bilinmektedir. AFP; endoderm kanser, teratoma, yumurtalık kanseri ve mide kanserinden karaciğer kanserine geçiş aşamalarında da görülür (Tang ve Ma, 2017). Gebelik döneminde düşük ve down sendromu gibi yaşanan olumsuz vakalarda da AFP miktarının artış gösterdiği tespit edilmiştir (Yuan ve ark., 2019). Karaciğer kanserinin teşhisi ve tedavisi için AFP her zaman hayati ve çok özel bir biyobelirteç olarak kabul edilir. Sağlıklı insan serumunda, AFP konsantrasyonu genellikle $20 \mathrm{ng} \mathrm{mL}^{-1}$ 'den düşükken, karaciğer kanseri hastalarında bu değer $20 \mathrm{ng} \mathrm{mL}^{-}$ ${ }^{1}$ 'den önemli ölçüde fazladır (Wu ve ark., 2019). Bu nedenle, kan serumundaki AFP seviyesinin tespiti büyük önem taşımaktadır. AFP'nin hassas ve seçici tayini için güvenilir metotların geliştirilmesi gerekmektedir. Çeşitli tayin metotları arasında, AFP'nin kantitatif tespiti için floresans spektroskopisi (Fang ve ark., 2018), kemilüminesans (Fan ve ark., 2014), elektrokemilüminesans (Liang ve ark., 2018), enzim-bağlı immunosorbent assay (ELISA) (Preechakasedkit ve ark., 2018), yüzey plazmon rezonansı (Wangkam ve ark., 2016), elektrokimyasal immünosensing (Yang ve ark., 2018; Li ve ark., 2018) ve fotoelektrokimyasal algılama (Zhou ve ark. 2018) gibi bir dizi yöntem önerilmiştir. Diğer yöntemlerle karşılaştırıldığında, elektrokimyasal immünosensörlerin ekonomik, hassas, taşınabilir ve kolay kullanım gibi birçok avantajı vardır ve yaygın olarak kullanılmaktadır (Bahadır ve Sezgintürk, 2015). Etiketli immünosensörler, uygulanan etiketin analitik özellikleri nedeniyle son derece hassas olmasına karşın zaman alıcı ve maliyetinin yüksek olması gibi dezavantajlara sahiptir. Etiketsiz immünosensörler, immünokompleks oluşumu sırasında fiziksel değişiklikleri algılayabilir, daha hassas ve çok yönlü tespitlere izin verir. Etiketsiz immünosensörler, potansiyel basitliği ve ekonomikliği ile immüno analiz sistemlerinde daha çok tercih edilir (Diaconu ve ark., 2013). Canlı serumunda AFP tayini için birçok etiketsiz elektrokimyasal immünosensör geliştirilmiştir (Wu ve ark., 2019; Liu ve ark., 2019; Lan ve ark., 2020; Jothi ve ark., 2020).

Grafen oksit (GO) ve indirgenmiş grafen oksitin (RGO), kolay sentezlenebilmesi, suda iyi çözünebilmesi, biyouyumluluğu ve yüksek yüzey alanı gibi özellikleri nedeniyle biyosensör üretimi, hücresel görüntüleme ve ilaç salınımı alanlarında potansiyel uygulamaları vardır (Zhou ve ark., 2019). Grafen, GO ve RGO sensör ve biyosensörlerde elektronik iletkenliği artırmak ve biyomateryalin immobilizasyonu için yaygın olarak kullanılmaktadır (Li ve ark., 2018; Yang ve ark., 2018). Nötral kırmızı (NR), virüsler gibi biyolojik materyalleri incelemek için bir renklendirici, biyokimyasal sistemlerde $\mathrm{pH}$ indikatörü, optik veya elektrokimyasal metotlar kullanarak DNA'nın incelenmesi gibi çeşitli amaçlarla kullanılan bir fenazin boyasıdır (Pauliukaite ve Brett, 2008). Son zamanlarda polinötral kırmızı (PNR), sensor ve biyosensörlerde hem iletken polimer hem de redoks medyatörü olarak kullanılan bir polimerdir (Attar ve ark., 2014; Sahin ve Ayranc1, 2015; Bilgi ve Ayranc1, 2016). Altın nanopartiküller (AuNP), yüksek yüzey/hacim oranına sahip olması, yüksek anodik potansiyellerde çalışma ihtiyacını ortadan kaldırması ve biyouyumluluk gibi özellikleri nedeniyle elektrokimyasal sensör ve biyosensörlerde yaygın olarak kullanılmaktadır (Putzbach ve Ronkainen, 2013; Bilgi ve Ayranc1, 2018). Yüzey baskılı elektrotlar (SPE), çeşitli inert substratlar üzerine farklı iletken veya yalıtkan mürekkep katmanlarının ardışık olarak yerleştirilmesini temel alır. SPE'lerin çok yönlü modifikasyona uygun olması, doğrudan yerinde ölçüm yapabilme imkani sunması, tek kullanımlık olması, hızlı ve basit olması, düşük maliyet gerektirmesi ve hasta başı testlere uygun olması gibi birçok avantaj1 vardır (Fanjul-Bolado ve ark., 2007; Tudorche ve Bala, 2007). 
Elektrokimyasal AFP immünosensörleri ile ilgili çok sayıda araştırma bulunmasına rağmen, RGO, PNR ve AuNP ile modifiye edilmiş tek kullanımlık SPCE elektrotları ile hazırlanan düşük maliyetli, pratik, hazırlanması kolay ve etiketsiz elektrokimyasal AFP immünosensörü literatürde yer almamaktadır. Bu çalışmada geliştirilen AFP immünosensörünün analitiksel performansı DPV ve SWV metotları ile incelenmiş, seçicilik testleri yapılmış, uygulama ve depolama kararlılıkları incelenmiştir. AFP immünosensörünün uygulanabilirliği insan kan serumu numunelerinde denenmiştir.

\section{MATERYAL VE YÖNTEM}

\section{Materyal}

Anti-AFP ve AFP Novus Biologicals USA firmasından, indirgenmiş grafen oksit (RGO), $\mathrm{HAuCl}_{4}$ (kloroaurik asit), sığır serum albümin (BSA), EDC (1-Etil,3-[3-dimetilaminopropil] karbodiimid), NHS (N-hidroksisüksinimid), insan serumu (erkek AB pıhtılaşmış tam kandan, H6914), potasyum hekzosiyanoferrat $\left(\mathrm{K}_{3} \mathrm{Fe}(\mathrm{CN})_{6}\right)$ potasyum hekzosiyanoferrit $\left(\mathrm{K}_{4} \mathrm{Fe}(\mathrm{CN})_{6}\right)$, sodyum hidroksit $(\mathrm{NaOH})$ Sigma-Aldrich firmasından, 3-merkaptopropiyonik asit (3-MPA), nötral kırmızı (NR), $\mathrm{KH}_{2} \mathrm{PO}_{4}$ (potasyum dihidrojen fosfat), $\mathrm{K}_{2} \mathrm{HPO}_{4}$ (dipotasyum hidrojen fosfat), $\mathrm{KCl}$ (potasyum klorür), dimetil formamid (DMF), hidroklorik asit (\%37'lik) ve etanol Merck firmasından tedarik edilmiştir. Kullanılan tüm kimyasallar yüksek analitik saflıktadır. Deneylerde Millipore Milli-Q Direct Q-3 ultra saf su cihazından elde edilen su kullanılmıştır. İstenilen $\mathrm{pH}$ 'da tampon çözelti hazırlamak için, standart tampon çözeltilerle kalibre edilmiş Mettler Toledo pH-metre kullanılmıştır. Tüm çözeltiler 50 mM pH 7.0 fosfat tamponu içerisinde hazırlanmıştır.

\section{Elektrokimyasal ölçümler}

Tek kullanımlık yüzey baskılı karbon elektrotlar (SPCE) DropSens (Oveido, İspanya) firmasından temin edilmiştir. SPCE'lerin çalışma elektrodu (4 mm) ve karşıt elektrodu karbondan, referans elektrodu ise $\mathrm{Ag} / \mathrm{AgCl}$ 'den $(0.1 \mathrm{M} \mathrm{KCl})$ oluşmaktadır. Elektrotların potantiyostata (Dropsens $\mu$ Stat 400 Bipotantiostat/Galvanostat, Oveido, İspanya) bağlantısı DropSens'ten temin edilmiş konnektörler ile sağlanmıştır. Tüm elektrokimyasal ölçümler, cihazın sinyalleri DropView 8400 yazılımı ile değerlendirilen bilgisayar kontrollü Dropsens $\mu$ Stat 400 Bipotentiostat/Galvanostat ile gerçekleştirilmiştir. Elektrokimyasal ölçümler ve deneyler en az 3 tekrarlı olarak gerçekleştirilmiştir.

\section{SPCE/RGO/PNR/AuNP elektrotlarının hazırlanması}

$0.5 \mathrm{mg}$ RGO ve $1.0 \mathrm{~mL}$ DMF: $\mathrm{H}_{2} \mathrm{O}$ (1:1) karışımına 3 saatlik sonikatör uygulamasıyla kararlı ve homojen bir süspansiyon hazırlanmıştır. Disperse edilmiş RGO'dan SPCE'lerin çalışma elektrodunun yüzeyine $2 \mu \mathrm{L}$ damlatılmış ve karanlıkta kapalı ortamda oda sıcaklığında kurumaya bırakılmıştır (SPCE/RGO) (Altun ve ark., 2020; Bilgi Kamaç ve ark., 2020a; 2020b). Daha sonra SPCE/RGO'ların üzerinde PNR oluşumu için, $0.025 \mathrm{M} \mathrm{pH} 5.5$ fosfat tamponu (0.1 $\left.\mathrm{M} \mathrm{KNO}_{3}\right)$ içerisinde hazırlanan 1.0 $\mathrm{mM}$ monomer nötral kırmızı çözeltisine $50 \mathrm{mV} \mathrm{s}^{-1}$ tarama hızında $-1.0 \mathrm{~V}$ ile $+0.9 \mathrm{~V}$ potansiyel aralığında 15 döngü dönüşümlü voltametri uygulanmıştır (Attar ve ark., 2014; Altun ve ark., 2020). Son olarak, SPCE/RGO/PNR'lerin üzerinde AuNP'nin hazırlanması için $4 \mathrm{mM} \mathrm{HAuCl}_{4}(50 \mathrm{mM} \mathrm{pH} 7.0$ fosfat tamponu, $0.1 \mathrm{M} \mathrm{KCl}$ ) çözeltisine $50 \mathrm{mV} \mathrm{s}^{-1}$ tarama hızında $-1.3 \mathrm{~V}$ ile $-0.2 \mathrm{~V}$ potansiyel aralığında 10 döngü dönüşümlü voltametri uygulanmıştır (Sonuç Karaboğa ve Sezgintürk, 2019). Her bir modifikasyon basamağından sonra, elektrotların yüzeyi ultra saf su ile yıkanmış ve yüksek saflıktaki Ar gazı ile kurutulmuştur. Hazırlanan SPCE/RGO/PNR/AuNP elektrotlarının elektrokimyasal karakterizasyonları için $5 \mathrm{mM}\left[\mathrm{Fe}(\mathrm{CN})_{6}\right]^{-3 /-4}(1 \mathrm{M} \mathrm{KCl})$ çözeltisinde $\mathrm{CV}$, DPV ve SWV ölçümleri yapılmıştır. 


\section{AFP immünosensörünün hazırlanması}

AFP immünosensörünün hazırlanmasında, Anti-AFP'nin yüzeye immobilizasyonu için kovalent bağlama yöntemi kullanılmıştır. $\mathrm{Bu}$ amaçla, SPCE/RGO/PNR/AuNP'lerin çalışma elektrotlarının yüzeyine $50 \mathrm{mM}$ 3-MPA (etanolde) çözeltisinden $3 \mu \mathrm{L}$ damlatılmış ve karanlıkta, oda sıcaklığında 1 gece bekletilmiştir (Sezgintürk, 2011). 3-MPA ile modifiye edilmiş SPCE/RGO/PNR/AuNP'lerin çalışma elektrotlarının yüzeyine $0.6 \mathrm{mM}$ EDC/0.1 mM NHS çözeltisinden (pH 7.0 fosfat tamponunda) $2 \mu \mathrm{L}$ damlatılmış ve oda sıcaklığında sabit nem ortamında $60 \mathrm{dk}$ bekletilmiştir (Demirbakan ve Sezgintürk, 2020). 3-MPA ve EDC/NHS ile aktive edilmiş çalışma elektrotlarının yüzeyine $2 \mu \mathrm{L}$ AntiAFP çözeltisinden damlatılmış ve oda sıcaklığında sabit nem ortamında $60 \mathrm{dk}$ bekletilmiştir. AntiAFP'nin immobilizasyonundan sonra, elektrotların yüzeyine bloke edici ajan olan BSA (\%1'lik, pH 7.0 fosfat tamponunda) çözeltisinden $2 \mu \mathrm{L}$ damlatılmış ve oda sıcaklığında sabit nem ortamında $30 \mathrm{dk}$ bekletilmiştir. Hazırlanan immünosensörlerin AFP analizinde kullanabilmesi için, bilinen konsantrasyondaki AFP çözeltisinden $2 \mu \mathrm{L}$ damlatılmış ve oda sıcaklığında sabit nem ortamında $15 \mathrm{dk}$ bekletilmiştir. AFP immünosensörlerinin her bir hazırlanma basamağından sonra, elektrotların yüzeyi ultra saf su ile yıkanmış ve yüksek saflıktaki Ar gazı ile kurutulmuştur. Hazırlanan AFP immünosensörünün elektrokimyasal karakterizasyonları için, $50 \mu \mathrm{g} \mathrm{mL} \mathrm{m}^{-1}$ AFP konsantrasyonunda hazırlanan immünosensörler ile $5 \mathrm{mM}\left[\mathrm{Fe}(\mathrm{CN})_{6}\right]^{-3 /-4}(1 \mathrm{M} \mathrm{KCl})$ çözeltisinde $\mathrm{CV}$, DPV ve SWV ölçümleri yapılmıştır. AFP immünosensörünün optimum çalışma parametrelerinin belirlenmesi için antikor konsantrasyon optimizasyonu, antikor ve antijen inkübasyon süre optimizasyon çalışmaları yapılmıştır.

\section{BULGULAR VE TARTIŞMA}

\section{SPCE/RGO/PNR/AuNP Elektrodunun Elektrokimyasal Karakterizasyonu}

$\mathrm{SPCE} / \mathrm{RGO} / \mathrm{PNR} / \mathrm{AuNP}$ elektrodunun formülasyonunda yer alan nanomateryallerin ve iletken redoks polimerinin etkisini incelemek için SPCE, SPCE/RGO, SPCE/PNR, SPCE/AuNP, SPCE/RGO/PNR, SPCE/RGO/AuNP, SPCE/PNR/AuNP ve SPCE/RGO/PNR/AuNP elektrotlar1 ile 5 $\mathrm{mM}\left[\mathrm{Fe}(\mathrm{CN})_{6}\right]^{-3 / 4}(1 \mathrm{M} \mathrm{KCl})$ çözeltisinde $\mathrm{CV}$, DPV ve SWV ölçümleri yapılmıştır. Elde edilen voltamogramlar Şekil 1A, 1B ve 1C'de, voltamogramlardan elde edilen pik akım değerleri ise Çizelge 1'de verilmiştir. SPCE üzerine RGO'nun modifikasyonu ile yalın SPCE elektroduna göre her üç metotta da elektronik iletkenliğin artışıyla birlikte pik akım değerlerinin arttı̆̆ görülmektedir (CV, DPV ve SWV için pik akım yükseklikleri farkı $(\Delta \mathrm{I})$ değerleri sırasıyla $3.2 \mu \mathrm{A}, 35.8 \mu \mathrm{A}$ ve $37.7 \mu \mathrm{A})$. RGO, elektronik iletkenliği artırıcı yönde etki etmiştir. SPCE yüzeyine sadece NR'nin elektropolimerizasyonu sonrasında elde edilen SPCE/PNR elektrodunda tüm metotlarda pik akım değerlerinin belirgin derecede azaldığı gözlenmiştir. Bu sonuçlar PNR'nin elektrot yüzeyine kaplandığını ve polimerin fillm kalınlığa bağlı olarak difüzyonu azaltıcı etki yaptığını göstermektedir. SPCE üzerine AuNP'nin modifikasyonuyla oluşan SPCE/AuNP elektrodunda elde edilen pik akım değerlerinin (CV, DPV ve SWV için $\triangle \mathrm{I}$ değerleri sırasıyla $148.1 \mu \mathrm{A}, 215.1 \mu \mathrm{A}$ ve $175.0 \mu \mathrm{A}$ ) yalın SPCE, SPCE/RGO ve SPCE/PNR elektrotlarına göre önemli ölçüde arttığı görülmüştür. Yalın SPCE'ye göre CV, DPV ve SWV için $\triangle \mathrm{I}$ değerleri sirasıyla $22.3 \mu \mathrm{A}, 28.2 \mu \mathrm{A}$ ve $27.2 \mu \mathrm{A}$ 'dir. Bu sonuçlara göre AuNP, RGO'ya göre elektronik iletkenliği daha fazla arttırmıştır. SPCE/PNR'ye göre CV, DPV ve SWV için $\triangle \mathrm{I}$ değerleri ise sırasıyla 143.2 $\mu \mathrm{A}, 206.8$ $\mu \mathrm{A}$ ve $170 \mu \mathrm{A}$ 'dir. SPCE/RGO/PNR elektrodunda elde edilen pik akım değerleri, SPCE/PNR elektrodunda elde edilen pik akım değerlerine yakın, SPCE/RGO elektrodunda elde edilen değerlerden oldukça düşüktür (Çizelge 1). RGO elektronik iletkenliği SPCE'ye göre belirgin derecede artırırken, aynı etki SPCE/RGO/PNR'de gözlenememiştir. Bu sonuçlara göre SPCE/RGO/PNR elektrodunda da 


\section{Kanser Biyobelirteci Alfa-Fetoproteinin Elektrokimyasal Tayini İçin Tek Kullanımlık Etiketsiz Yeni} AFP İmmünosensörünün Geliștirilmesi

yüzeyde oluşan polimer film tabakası nedeniyle PNR difüzyonu azaltıcı yönde etki etmiştir. PNR'nin yer aldığı diğer elektrot olan SPCE/PNR/AuNP elektrodunda ise, pik akım değerlerinin hem SPCE/PNR (CV, DPV ve SWV için $\Delta \mathrm{I}$ değerleri sırasıyla 149.2 $\mu \mathrm{A}, 223.4 \mu \mathrm{A}$ ve 189.4 $\mu \mathrm{A}$ ) hem de SPCE/AuNP'ye (CV, DPV ve SWV için $\Delta \mathrm{I}$ değerleri sırasıyla $6.0 \mu \mathrm{A}, 16.6 \mu \mathrm{A}$ ve $19.4 \mu \mathrm{A}$ ) göre arttığ Şekil 1A, 1B ve $1 C$ 'deki voltamogramlardan ve Çizelge 1'den anlaşılmaktadır. PNR ve AuNP birlikte sinerjik bir etki göstermiş ve elektronik iletkenliği artırmıştır. SPCE/RGO/AuNP elektrodunun pik akım değerleri ise, SPCE/RGO (CV, DPV ve SWV için $\triangle \mathrm{I}$ değerleri sırasıyla $27.5 \mu \mathrm{A}, 29.5 \mu \mathrm{A}$ ve $46.6 \mu \mathrm{A}$ ) ve SPCE/AuNP'ye (CV, DPV ve SWV için $\triangle \mathrm{I}$ değerleri sırasıyla $5.2 \mu \mathrm{A}, 1.3 \mu \mathrm{A}$ ve $19.4 \mu \mathrm{A})$ göre daha fazladır. Bu durum RGO ve AuNP'nin birlikte sinerjik bir etki yaparak elektronik iletkenliği arttırdığını göstermektedir. SPCE/RGO/PNR/AuNP elektrodunda ise tüm metotlarda elde edilen pik akım değerleri incelendiğinde, en yüksek değerlere ulaşıldığı anlaşılmaktadır. RGO, PNR ve AuNP materyallerinin hepsinin elektrot formülasyonunda yer alması sinerjik bir etki yaratarak elektronik iletkenliği oldukça fazla artırmıştır (Şahin ve Ayrancı, 2015; Bilgi Kamaç ve ark., 2020a; 2020b).
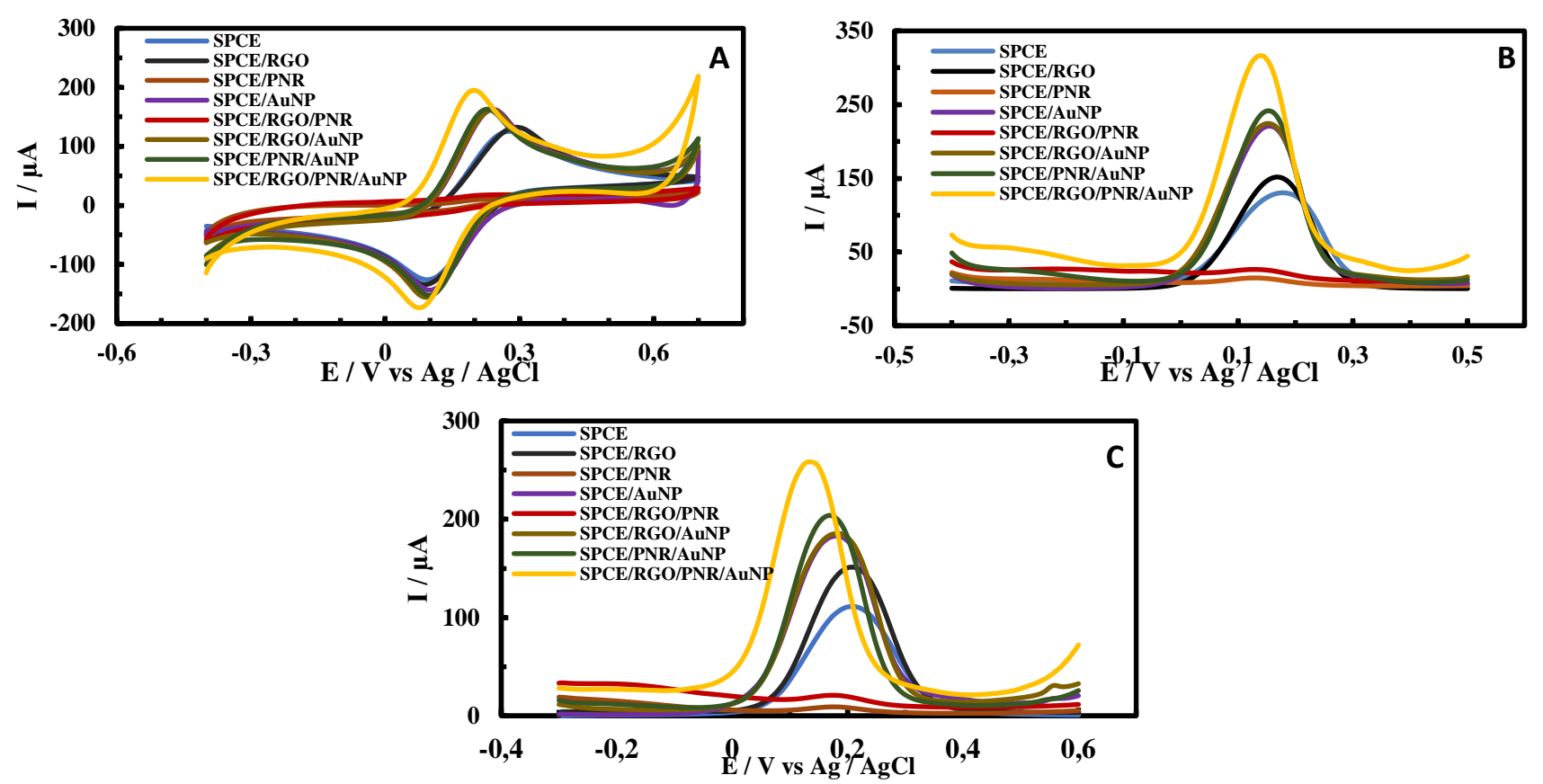

Şekil 1. (A) SPCE, SPCE/RGO, SPCE/PNR, SPCE/AuNP, SPCE/RGO/PNR, SPCE/RGO/AuNP, SPCE/PNR/AuNP ve SPCE/RGO/PNR/AuNP elektrotlarının $5 \mathrm{mM}\left[\mathrm{Fe}(\mathrm{CN})_{6}\right]^{-3 / 4}(1 \mathrm{M} \mathrm{KCl})$ çözeltisinde $-0.4 \mathrm{~V}$ ile $+0.7 \mathrm{~V}$ potansiyel aralığında elde edilen dönüşümlü voltamogramları (srate: $50 \mathrm{mV} \mathrm{s}$ ${ }^{1}$ ), (B) $-0.4 \mathrm{~V}$ ile $+0.5 \mathrm{~V}$ potansiyel aralığında elde edilen diferansiyel puls voltamogramları ( $\mathrm{E}_{\text {puls }}: 70 \mathrm{mV}, \mathrm{t}_{\text {puls }}: 0.1 \mathrm{~s}, \mathrm{E}_{\text {step }}: 5 \mathrm{mV}$, srate: $\left.10 \mathrm{mV} \mathrm{s}{ }^{-1}\right),(\mathbf{C})-0.3$ $\mathrm{V}$ ile $+0.6 \mathrm{~V}$ potansiyel aralı̆̆ında elde edilen kare dalga voltamogramları ( $\mathrm{E}_{\text {step }}: 5 \mathrm{mV}, \mathrm{E}_{\text {amp }}: 25 \mathrm{mV}$, Freq: $5 \mathrm{~Hz}$ )

Çizelge 1. SPCE/RGO/PNR/AuNP elektrodunun hazırlanma basamaklarında CV, DPV ve SWV'lerden elde edilen pik akımı yükseklikleri

\begin{tabular}{lrrr}
\hline Elektrot türü & \multicolumn{1}{c}{$\mathbf{C V}(\boldsymbol{\mu A})$} & \multicolumn{1}{c}{ DPV $(\boldsymbol{\mu A})$} & \multicolumn{1}{c}{ SWV $(\boldsymbol{\mu A})$} \\
\hline SPCE & $122.6 \pm 0.26$ & $151.1 \pm 0.23$ & $110.1 \pm 0.24$ \\
SPCE/RGO & $125.8 \pm 0.41$ & $186.9 \pm 0.34$ & $147.8 \pm 0.37$ \\
SPCE/PNR & $4.9 \pm 0.07$ & $8.3 \pm 0.06$ & $5.0 \pm 0.09$ \\
SPCE/AuNP & $148.1 \pm 0.14$ & $215.1 \pm 0.17$ & $175.0 \pm 0.12$ \\
SPCE/RGO/PNR & $5.1 \pm 0.13$ & $9.0 \pm 0.11$ & $7.3 \pm 0.08$ \\
SPCE/RGO/AuNP & $153.3 \pm 0.56$ & $216.4 \pm 0.49$ & $175.3 \pm 0.51$ \\
SPCE/PNR/AuNP & $154.1 \pm 0.43$ & $231.7 \pm 0.39$ & $194.4 \pm 0.41$ \\
SPCE/RGO/PNR/AuNP & $170.0 \pm 0.71$ & $288.2 \pm 0.68$ & $234.0 \pm 0.66$ \\
\hline
\end{tabular}




\section{Kanser Biyobelirteci Alfa-Fetoproteinin Elektrokimyasal Tayini İçin Tek Kullanımlık Etiketsiz Yeni} AFP İmmünosensörünün Geliştirilmesi

\section{AFP İmmünosensörünün Elektrokimyasal Karakterizasyonu}

AFP immünosensörünün elektrokimyasal karakterizasyonu için $50 \mu \mathrm{g} \mathrm{mL}^{-1}$ AFP konsantrasyonunda hazırlanan immünosensörler ile $5 \mathrm{mM}\left[\mathrm{Fe}(\mathrm{CN})_{6}\right]^{-3 /-4}(1 \mathrm{M} \mathrm{KCl})$ çözeltisinde $\mathrm{CV}$, DPV ve SWV ölçümleri yapılmıştır. AFP immünosensörünün hazırlanma basamaklarına ait CV, DPV ve SWV'ler sirasıyla Şekil 2A, 2B ve 2C'de, voltamogramlardan elde edilen pik akım değerleri ise Çizelge 2'de verilmiştir. Anti-AFP'nin elektrot yüzeyine tutuklanması sonrasında EDC-NHS/Anti-AFP elektrodunun pik akım değerleri üç metotta da azalmıştır. Bu azalışın nedeni, antikorun elektrodun yüzeyini EDC-NHS basamağına göre daha yalıtkan hale getirmesi ve sonrasında elektronların elektrot yüzeyine difüzyonunu azaltmasıdır. Bu sonuç, anti-AFP'nin elektrot yüzeyine başarılı bir şekilde kovalent bağlandığını göstermektedir. BSA bloklama ajanının modifikasyonu sonrasında ise her üç metottan elde edilen değerlere göre EDC-NHS/Anti-AFP/BSA immünosensörünün yüzeyinde, EDCNHS/Anti-AFP elektroduna göre daha yalıtkan bir tabaka oluşmuş ve bunun sonucu olarak da elektronların elektrot yüzeyine difüzyonu azalmıştır. Elektron difüzyonunun azalması ile pik akım değerleri de azalmıştır. Son basamakta ise AFP'nin immünosensör yüzeyine immobilizasyonu ile AFP immünosensörünün yalıtkanlığı daha da artmış, iletkenliği azalmış ve pik akım değerleri de azalma göstermiştir (Aydın ve Sezgintürk, 2017; Demirbakan ve Sezgintürk, 2020). Bu sonuçlar AFP immünosensörünün başarılı bir şekilde hazırlandığını göstermektedir.
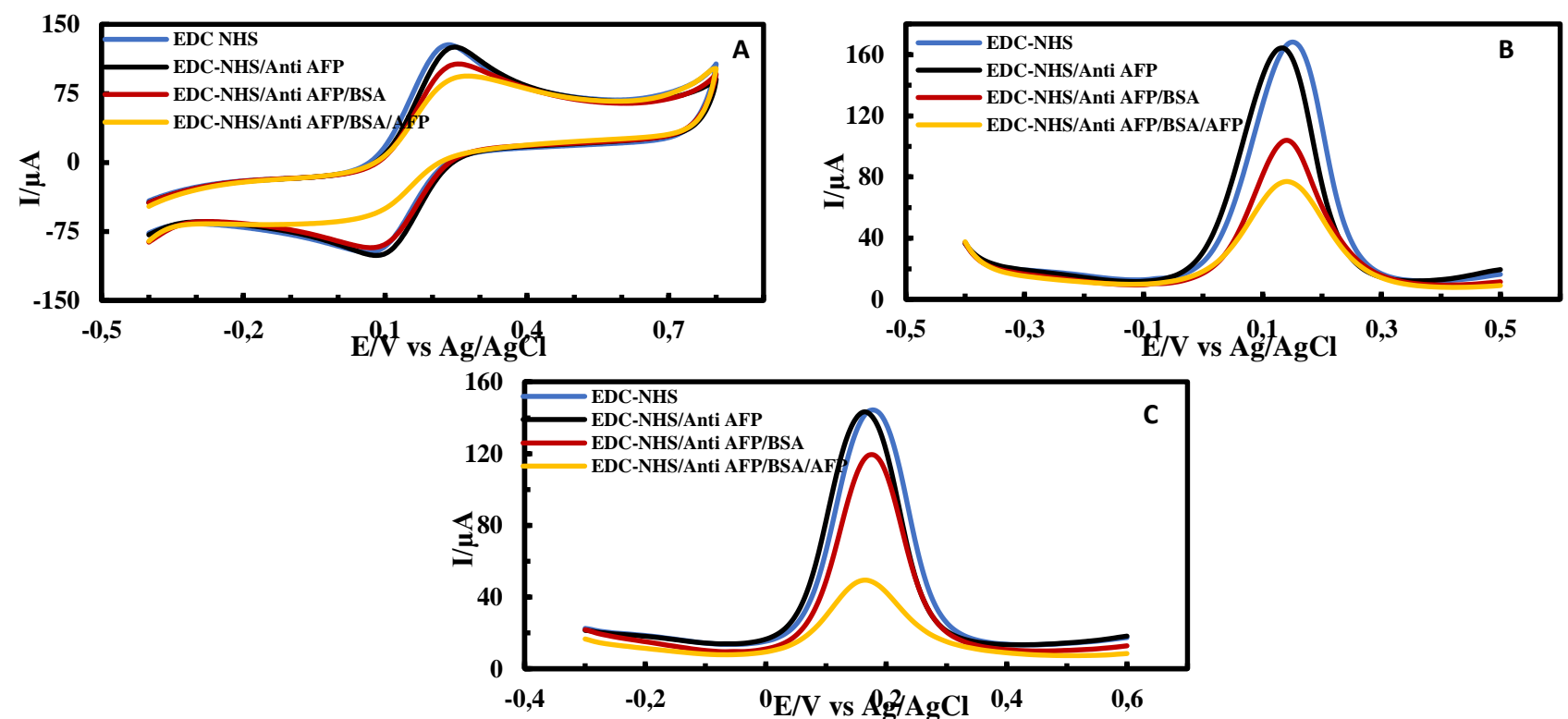

Şekil 2. AFP immünosensörünün hazırlanma basamaklarının $5 \mathrm{mM}\left[\mathrm{Fe}(\mathrm{CN})_{6}\right]^{-3 / 4}(1 \mathrm{M} \mathrm{KCl})$ çözeltisinde $(\mathbf{A})-0.4 \mathrm{~V}$ ile $+0.8 \mathrm{~V}$ potansiyel aralığında elde edilen döngüsel voltamogramları (srate: $\left.50 \mathrm{mV} \mathrm{s}^{-1}\right),(\mathbf{B})-0.4 \mathrm{~V}$ ile $+0.5 \mathrm{~V}$ potansiyel aralığında elde edilen diferansiyel puls voltamogramları $\left(\mathrm{E}_{\text {puls }}: 70 \mathrm{mV}\right.$, $t_{\text {puls: }}: 0.1 \mathrm{~s}, \mathrm{E}_{\text {step }}: 5 \mathrm{mV}$, srate: $\left.10 \mathrm{mV} \mathrm{s}{ }^{-1}\right),(\mathbf{C})-0.3 \mathrm{~V}$ ile $+0.6 \mathrm{~V}$ potansiyel aralı̆̆ında elde edilen kare dalga voltamogramları $\left(\mathrm{E}_{\text {step }}: 5 \mathrm{mV}, \mathrm{E}_{\text {amp }}: 25 \mathrm{mV}\right.$, Freq: $5 \mathrm{~Hz})$

Çizelge 2. AFP immünosensörünün hazırlanma basamaklarında CV, DPV ve SWV'lerden elde edilen pik akımı yükseklikleri

\begin{tabular}{lcrc}
\hline Elektrot türü & $\mathrm{CV}(\mu \mathrm{A})$ & $\mathrm{DPV}(\mu \mathrm{A})$ & $\mathrm{SWV}(\mu \mathrm{A})$ \\
\hline EDC-NHS & $110.4 \pm 0.30$ & $155.6 \pm 0.27$ & $130.8 \pm 0.23$ \\
EDC-NHS/Anti-AFP & $108.4 \pm 0.39$ & $152.4 \pm 0.32$ & $129.7 \pm 0.33$ \\
EDC-NHS/Anti-AFP/BSA & $90.1 \pm 0.24$ & $94.2 \pm 0.22$ & $109.4 \pm 0.21$ \\
EDC-NHS/Anti-AFP/BSA/AFP & $72.6 \pm 0.18$ & $68.1 \pm 0.16$ & $41.7 \pm 0.13$ \\
\hline
\end{tabular}

\section{AFP İmmünosensörünün Optimum Çalışma Parametrelerinin Belirlenmesi}

Anti-AFP antikor konsantrasyonunun optimizasyonu için üç farklı anti-AFP konsantrasyonuna $\left(25 \mu \mathrm{g} \mathrm{mL} L^{-1}, 50 \mu \mathrm{g} \mathrm{mL}^{-1}\right.$ ve $\left.75 \mu \mathrm{g} \mathrm{mL}^{-1}\right)$ sahip AFP immünosensörleri hazırlanmıştır. Hazırlanan AFP 
immünosensörleri farklı konsantrasyonlardaki AFP'nin analizi için kullanılmıştır. Bu amaçla farklı AFP immünosensörlerinin $5 \mathrm{mM}\left[\mathrm{Fe}(\mathrm{CN})_{6}\right]^{-3 /-4}(1 \mathrm{M} \mathrm{KCl})$ çözeltisinde DPV ve SWV metotları ile farklı konsantrasyonlardaki AFP antijenine karşı ölçümleri alınmıştır. DPV ve SWV ölçümlerinden elde edilen akım farkı değerlerinin farklı AFP konsantrasyon değerlerine karşı çizilen grafikleri sırasıyla Şekil 3A ve 3B'de, grafiklerden elde edilen duyarlık ve korelasyon katsayısı değerleri ise Çizelge 3 'te verilmiştir. En yüksek duyarlık değeri DPV metodu ile $50 \mu \mathrm{g} \mathrm{mL}^{-1}$, SWV metodu ile $25 \mu \mathrm{g} \mathrm{mL}^{-1}$ anti-AFP konsantrasyonunda elde edilmiş ve her iki duyarlık değerlerinin birbirine yakın olduğu görülmüştür. 50 $\mu \mathrm{g} \mathrm{mL} \mathrm{m}^{-1}$ anti-AFP konsantrasyonu için her iki metotta elde edilen korelasyon katsayısı değerleri en yüksektir. Duyarlık ve korelasyon katsayısı değerlerinin her ikisi de göz önünde bulundurulduğunda optimum anti-AFP konsantrasyonu $50 \mu \mathrm{g} \mathrm{mL} \mathrm{m}^{-1}$ olarak belirlenmiştir. Çalışmanın bundan sonraki kısımlarında AFP immünosensörleri $50 \mu \mathrm{g} \mathrm{mL}^{-1}$ anti-AFP konsantrasyonunda hazırlanmıştır.
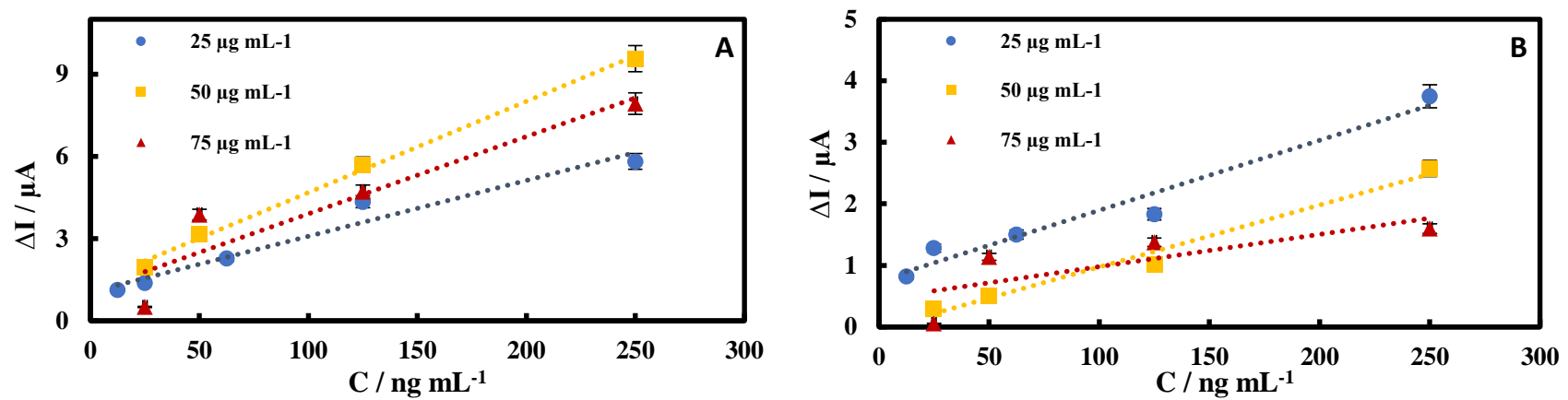

Şekil 3. Farklı konsantrasyonlardaki anti-AFP ile hazırlanan SPCE/RGO/PNR/AuNP/ Anti-AFP/BSA immünosensörlerinin farklı konsantrasyonlardaki AFP antijenine karşı $5 \mathrm{mM}\left[\mathrm{Fe}(\mathrm{CN})_{6}\right]^{-3 / 4}(1 \mathrm{M} \mathrm{KCl})$ çözeltisinde (A) DPV cevabına etkileri, (B) SWV cevabına etkileri

Çizelge 3. Şekil 3A ve 3B'de verilen grafiklerinden elde edilen duyarlık ve korelasyon katsayısı değerleri

\begin{tabular}{lccc}
\hline Metot & Anti-AFP konsantrasyonu $\left(\boldsymbol{\mu} \mathbf{g ~ m L}^{-\mathbf{1}}\right)$ & Duyarlık $\left(\boldsymbol{\mu} \mathbf{A} \mathbf{~ m L ~} \mathbf{~ g}^{-\mathbf{1}}\right)$ & Korelasyon katsayısı $(\mathbf{r})$ \\
\hline \multirow{3}{*}{ DPV } & 25 & $0.0204 \pm 0.0003$ & 0.9774 \\
& 50 & $0.0333 \pm 0.0007$ & 0.9981 \\
& 75 & $0.028 \pm 0.0005$ & 0.9330 \\
\hline \multirow{3}{*}{ SWV } & 25 & $0.0114 \pm 0.0001$ & 0.9796 \\
& 50 & $0.0101 \pm 0.0003$ & 0.9898 \\
& 75 & $0.0053 \pm 0.0001$ & 0.7755 \\
\hline
\end{tabular}

Optimum anti-AFP konsantrasyonunu belirledikten sonra, anti-AFP inkübasyon süresinin optimizasyonu basamağına geçilmiştir. Burada amaç, anti-AFP'nin hangi inkübasyon süresinde en verimli şekilde yüzeye bağlanabileceğini tespit etmektir. Anti-AFP inkübasyon süresinin optimizasyonu için farklı anti-AFP (50 $\left.\mu \mathrm{g} \mathrm{mL}^{-1}\right)$ inkübasyon sürelerinde (30, 45 ve $60 \mathrm{dk}$ ) AFP immünosensörleri hazırlanmıştır. Hazırlanan AFP immünosensörleri, farklı konsantrasyonlardaki AFP'nin analizi için kullanılmıştır. Farklı AFP immünosensörlerinin $5 \mathrm{mM}\left[\mathrm{Fe}(\mathrm{CN})_{6}\right]^{-3 /-4}(1 \mathrm{M} \mathrm{KCl})$ çözeltisinde DPV ve SWV metotları ile farklı konsantrasyonlardaki AFP antijenine karşı ölçümleri alınmıştır. DPV ve SWV ölçümlerinden elde edilen akım farkı değerlerinin farklı AFP konsantrasyon değerlerine karşı çizilen grafikleri sırasıyla Şekil 4A ve 4B'de, grafiklerden elde edilen duyarlık ve korelasyon katsayısı değerleri ise Çizelge 4'te verilmiştir. DPV metodunda $30 \mathrm{dk}$ ve $45 \mathrm{dk}$ inkübasyon sürelerinde elde edilen duyarlık değerlerinin birbirine yakın olmasına karşın, $45 \mathrm{dk}$ inkübasyon süresinde korelasyon çok daha fazladır. SWV metodunda ise $30 \mathrm{dk}$ inkübasyon süresinde elde edilen duyarlık değeri $45 \mathrm{dk}$ 'da elde edilen değerden daha fazla olmasına karşın, korelasyon katsayısı değerleri $45 \mathrm{dk}$ 'da daha fazladır. Korelasyon katsayıları göz önüne alındığında $30 \mathrm{dk}$ inkübasyon süresinin anti-AFP'nin immobilizasyonu için 
yeterince iyi olmadığını göstermektedir. $60 \mathrm{dk}$ inkübasyon süresinde ise her iki metotta da en yüksek duyarlık ve korelasyon katsayısı değerleri elde edilmiştir. Bu sonuçlara göre optimum anti-AFP inkübasyon süresi $60 \mathrm{dk}$ olarak belirlenmiştir. Literatürde de antikorların yüzeye immobilizasyonu genellikle 30 ile $60 \mathrm{dk}$ arasındadır. Bulduğumuz sonuçlar literatür ile de uyumludur (Aydın ve Sezgintürk, 2017; Aydın ve ark., 2017). Çalışmanın bundan sonraki kısmında, $50 \mu \mathrm{g} \mathrm{mL} \mathrm{m}^{-1}$ konsantrasyonundaki anti-AFP'ler $60 \mathrm{dk}$ inkübe edilerek AFP immünosensörleri hazırlanmıştır.
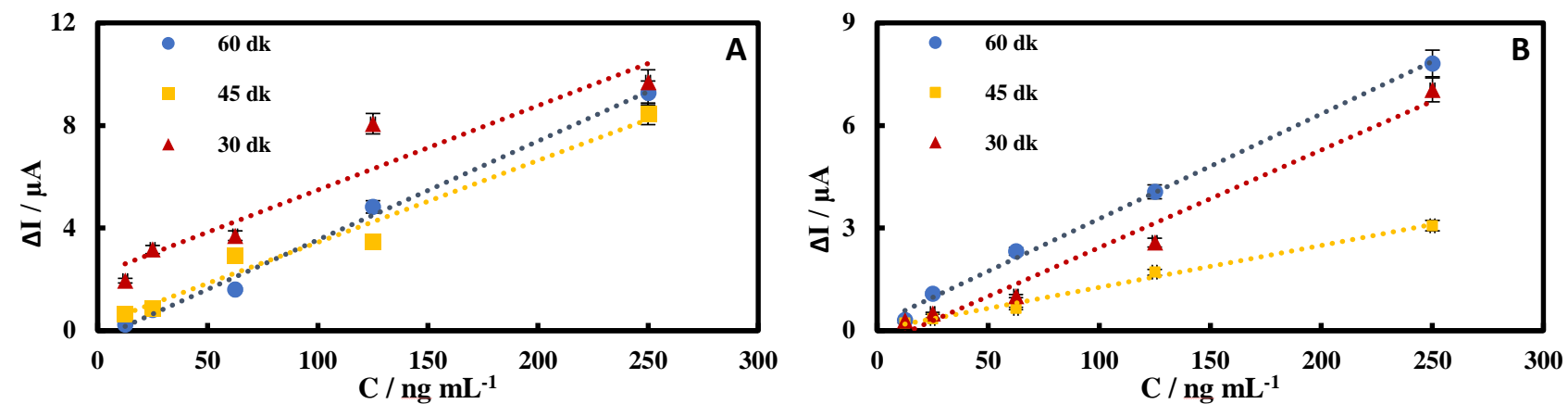

Şekil 4. Farklı anti-AFP inkübasyon sürelerinde hazırlanan SPCE/RGO/PNR/AuNP/Anti-AFP/BSA immünosensörlerinin farklı konsantrasyonlardaki AFP antijenine karşı $5 \mathrm{mM}\left[\mathrm{Fe}(\mathrm{CN})_{6}\right]^{-3 / 4}(1 \mathrm{M} \mathrm{KCl})$ çözeltisinde (A) DPV cevabına etkileri B) SWV cevabına etkileri

Çizelge 4. Şekil 4A ve 4B'de verilen grafiklerinden elde edilen duyarlık ve korelasyon katsayısı değerleri

\begin{tabular}{lccc}
\hline Metot & Anti-AFP inkübasyon süresi (dk) & Duyarlık $\left(\boldsymbol{\mu A} \mathbf{~ m L ~ n g}^{-\mathbf{1}}\right)$ & Korelasyon katsayısı (r) \\
\hline & 30 & $0.0329 \pm 0.0006$ & 0.950 \\
DPV & 45 & $0.0320 \pm 0.0003$ & 0.986 \\
& 60 & $0.0386 \pm 0.0002$ & 0.997 \\
\hline \multirow{3}{*}{ SWV } & 30 & $0.0285 \pm 0.0003$ & 0.988 \\
& 45 & $0.0123 \pm 0.0006$ & 0.996 \\
& 60 & $0.0307 \pm 0.0001$ & 0.998 \\
\hline
\end{tabular}

Çalışmanın bu aşamasında, elektrot yüzeyine AFP antijeninin maksimum verimde bağlanabileceği inkübasyon süresi belirlenmiştir. Bu amaçla optimum şartlarda farklı AFP inkübasyon sürelerinde $(15,30$ ve $45 \mathrm{dk})$ AFP immünosensörleri hazırlanmış ve farklı konsantrasyonlardaki AFP'nin analizi için kullanılmıştır. Farklı AFP immünosensörlerinin $5 \mathrm{mM}\left[\mathrm{Fe}(\mathrm{CN})_{6}\right]^{-3 /-4}(1 \mathrm{M} \mathrm{KCl})$ çözeltisinde DPV ve SWV metotları ile farklı konsantrasyonlardaki AFP antijenine karşı ölçümleri alınmıştır. DPV ve SWV ölçümlerinden elde edilen akım farkı değerlerinin farklı AFP konsantrasyon değerlerine karşı çizilen grafikleri sırasıyla Şekil 5A ve 5B'de, grafiklerden elde edilen duyarlık ve korelasyon katsayısı değerleri ise Çizelge 5 'te verilmiştir. Her iki metotta da en yüksek duyarlık değeri 15 dk AFP inkübasyon süresinde elde edilmiştir. 15 dakika AFP inkübasyon süresinde DPV metodu ile elde edilen korelasyon katsayısının düşük olmasına karşın, SWV metodunda en yüksek değerdedir. DPV ve SWV metotları ile elde edilen duyarlık ve korelasyon katsayısı değerleri göz önüne alındığında, AFP'nin tespiti için $15 \mathrm{dk}$ AFP inkübasyon süresinde, immünosensörden çok daha yüksek performans elde edileceği sonucuna varılmıştır ve optimum AFP inkübasyon süresi $15 \mathrm{dk}$ olarak belirlenmiştir (Aydın ve Sezgintürk, 2017; Aydın ve ark., 2017). 

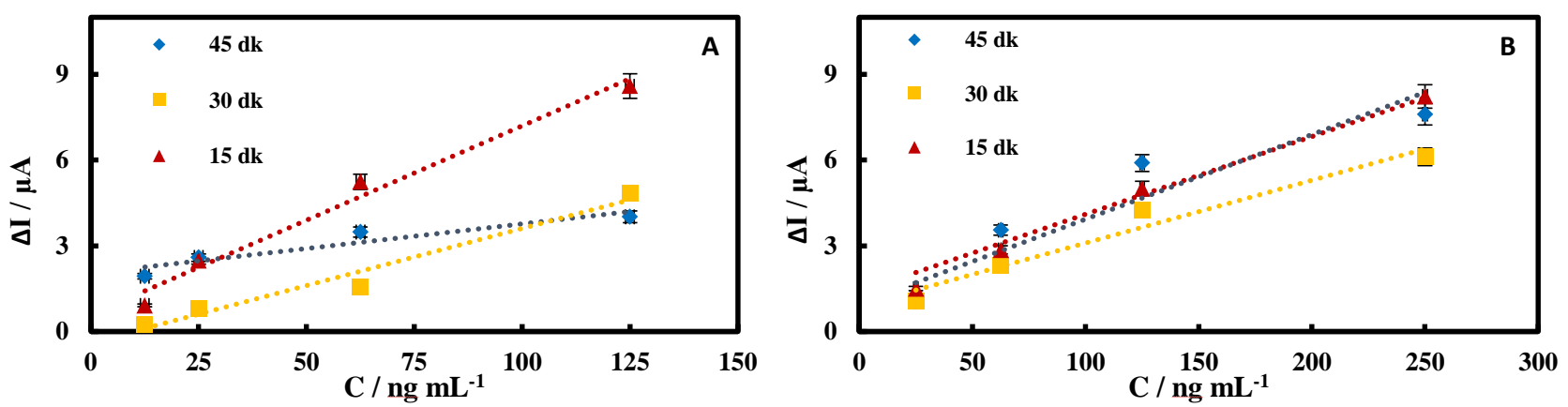

Şekil 5. AFP'nin inkübasyon sürelerinin SPCE/RGO/PNR/AuNP/Anti-AFP/BSA immünosensörünün farklı AFP antijenine karş1 $5 \mathrm{mM}\left[\mathrm{Fe}(\mathrm{CN})_{6}\right]^{-3 / 4}(1 \mathrm{M}$ $\mathrm{KCl}$ ) çözeltisinde (A) DPV cevabına etkileri, (B) SWV cevabına etkileri

Çizelge 5. Şekil 5A ve 5B'de verilen grafiklerinden elde edilen duyarlık ve korelasyon katsayısı değerleri

\begin{tabular}{lccc}
\hline Metot & AFP'nin inkübasyon süresi (dk) & Duyarlık $\left(\boldsymbol{\mu} \mathbf{A} \mathbf{~ m L ~}_{\mathbf{~ n}} \mathbf{- 1}^{\mathbf{1}}\right)$ & Korelasyon katsayısı (r) \\
\hline \multirow{3}{*}{ DPV } & 15 & $0.0660 \pm 0.0006$ & 0.803 \\
& 30 & $0.0400 \pm 0.0005$ & 0.996 \\
& 45 & $0.0173 \pm 0.0004$ & 0.936 \\
\hline \multirow{2}{*}{ SWV } & 15 & $0.0296 \pm 0.0005$ & 0.997 \\
& 30 & $0.0220 \pm 0.0002$ & 0.980 \\
& 45 & $0.0271 \pm 0.0005$ & 0.941 \\
\hline
\end{tabular}

\section{Analitiksel Karakterizasyon}

Sağlıklı insan serumunda AFP seviyesi $25 \mathrm{ng} \mathrm{mL} \mathrm{mL}^{-1}$ den daha düşük bir konsantrasyondadır. Ancak yaklaşık \%75 HCC hastasında $500 \mathrm{ng} \mathrm{mL}^{-1}$ ye yükselir (Li ve ark., 2018; Wu ve ark., 2019). Çalışmamızda optimum şartlarda hazırlanan AFP immünosensörlerinin analitiksel performanslarının tespiti için 1-500 ng mL ${ }^{-1}$ konsantrasyon aralığında artan AFP konsantrasyonuna karşı $5 \mathrm{mM}\left[\mathrm{Fe}(\mathrm{CN})_{6}\right]^{-}$ 3/-4 (1 M KCl) çözeltisinde DPV ve SWV metotları ile ölçüm alınarak analitiksel karakterizasyonları yapılmıştır. Artan AFP konsantrasyonuna karşı DPV ve SWV'den elde edilen pik akım değeri grafikleri sırasıyla Şekil 6A ve 6B'de verilmiştir. AFP derişimi artışı ile pik akım değerleri de doğru orantılı olarak arttığı verilen grafiklerden anlaşılmaktadır. AFP'nin voltametrik tayininde kullanılan SPCE/RGO/PNR/AuNP/Anti-AFP/BSA immünosensörlerinin analitiksel karakterizasyonu için duyarlık, tayin ve tespit sınırı parametreleri belirlenmiş ve Çizelge 6'da verilmiştir. Her iki metotta da yüksek duyarlık ve korelasyon katsayısı değerleri elde edilmiştir. AFP immünosensörünün tekrarlanabilirliği $50 \mathrm{ng} \mathrm{mL}^{-1} \mathrm{AFP}$ derişiminde DPV ve SWV metotları ile test edilmiş ve bağıl standart sapma (RSD) değerleri sırasıyla \%4.06 $(n=10)$ ve \%3.68 $(n=10)$ olarak hesaplanmıştır. Her iki metot verilerine göre tekrarlanabilirlik için hesaplanan RSD değerleri, 10 tekrara kadar AFP tayininin iyi olduğunu göstermektedir.
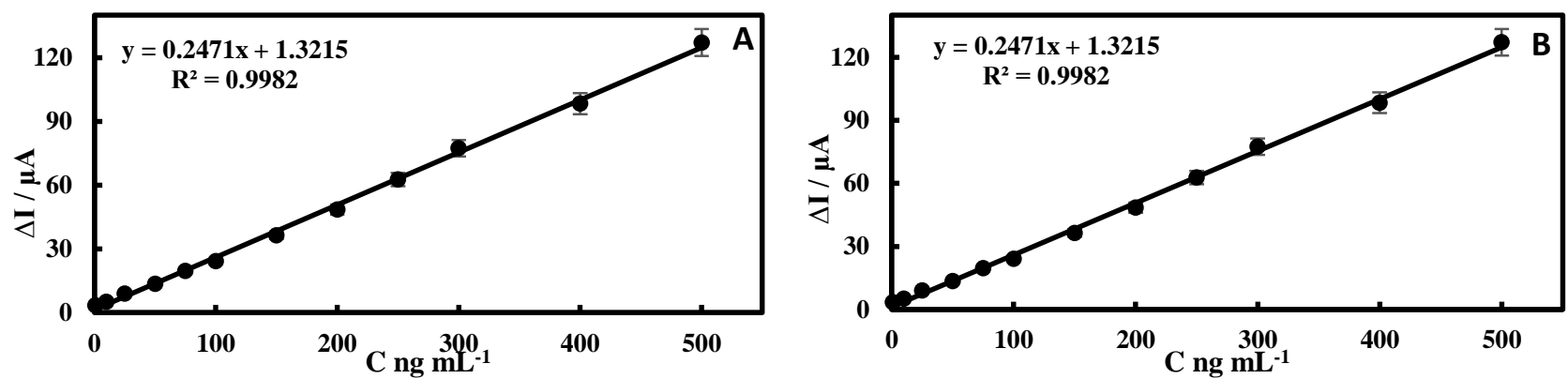

Şekil 6. AFP immünosensörü ile 1-500 $\mathrm{ng} \mathrm{mL}^{-1}$ konsantrasyon aralığında artan AFP derişimine karşı (A) DPV (B) SWV'den elde edilen pik akım değerleri grafikleri 


\section{Kanser Biyobelirteci Alfa-Fetoproteinin Elektrokimyasal Tayini İçin Tek Kullanımlık Etiketsiz Yeni} AFP İmmünosensörünün Geliştirilmesi

Çizelge 6. AFP'nin tayini için SPCE/RGO/PNR/AuNP/Anti-AFP/BSA immünosensörleri ile elde edilen analitiksel parametreler

\begin{tabular}{lccccc}
\hline Metot & Tayin aralı̆̆ı & Duyarlık & Tespit Limiti & Tayin Sınırı & Korelasyon katsayısı (r) \\
\hline DPV & $1-500 \mathrm{ng} \mathrm{mL}^{-1}$ & $0.247 \mu \mathrm{A} \mathrm{mL} \mathrm{ng}^{-1}$ & $0.79 \mathrm{ng} \mathrm{mL}^{-1}$ & $2.61 \mathrm{ng} \mathrm{mL}^{-1}$ & 0.9991 \\
SWV & $1-500 \mathrm{ng} \mathrm{mL}^{-1}$ & $0.183 \mu \mathrm{AmL} \mathrm{ng}^{-1}$ & $0.86 \mathrm{ng} \mathrm{mL}^{-1}$ & $2.84 \mathrm{ng} \mathrm{mL}^{-1}$ & 0.9980 \\
\hline
\end{tabular}

SPCE/RGO/PNR/AuNP/Anti-AFP/BSA immünosensörünün uygulama kararlılığının tespiti için, $50 \mathrm{ng} \mathrm{mL}^{-1}$ sabit AFP konsantrasyonunda AFP immünosensörleri hazırlanmış ve $5 \mathrm{mM}\left[\mathrm{Fe}(\mathrm{CN})_{6}\right]^{-}$ 3/-4 $(1 \mathrm{M} \mathrm{KCl})$ çözeltisinde 60 gün boyunca belirli aralıklarla DPV ve SWV metotları ile ölçümler yapılmıştır. AFP immünosensörleri 60 gün boyunca $+4{ }^{\circ} \mathrm{C}$ 'de inkübatörde bekletilmiştir. DPV ve SWV metotları ile yapılan ölçümlerden elde edilen AFP'ye karşı immünosensör cevabının ilk günkü akım ortalamasına göre yüzde bağıl akım değerleri hesaplanmış ve zamana karşı grafiği çizilmiştir (Şekil 7A). AFP immünosensörünün \% ortalama bağıl akım değeri 3. günün sonunda \%5.6, 10. günün sonunda $\% 17.64$, 30. günün sonunda $\% 44.31,60$. gün sonunda $\% 72.91$ oranında azalmıştır. SPCE/RGO/PNR/AuNP/Anti-AFP/BSA immünosensörünün uygulama kararlılığı ilk kullanımdan sonra azalmış olsa da 60. güne kadar AFP için yanıt vermiştir. Tek kullanımlık olarak hazırlanan bir immünosensör için 60 gün boyunca uygulama kararlılığının iyi olduğu ve immünosensör formülasyonunda bulunan RGO, PNR ve AuNP'nin uygulama kararlılığını arttırdığı sonucuna varılabilir. SPCE/RGO/PNR/AuNP/Anti-AFP/BSA immünosensörünün depolama kararlığını belirlemek için, optimum şartlarda $50 \quad \mathrm{ng} \mathrm{mL}^{-1}$ sabit AFP konsantrasyonunda hazırlanan immünosensörler $-20{ }^{\circ} \mathrm{C}$ 'de bekletilmiştir. AFP immünosensörlerin $5 \mathrm{mM}\left[\mathrm{Fe}(\mathrm{CN})_{6}\right]^{-3 /-4}(1 \mathrm{M} \mathrm{KCl})$ çözeltisinde DPV ve SWV metotları ile 12 hafta boyunca belirli aralıklarla ölçümleri yapılmıştır. Voltametrik tayinler sonucu elde edilen \%ortalama bağıl akım-hafta sayısı grafiği Şekil 7B'de verilmiştir. AFP immünosensörünün \% ortalama bağıl akım değeri 1. haftanın sonunda ilk güne göre $\% 16.5,2$. haftanın sonunda $\% 24.8,8$. haftanın sonunda $\% 43.2$ ve 12 . haftanın sonunda ise $\% 58.7$ azalma göstermiştir. $\mathrm{Bu}$ veriler, ilk güne göre bağıl akımda azalma olmasına karşın SPCE/RGO/PNR/AuNP/Anti-AFP/BSA immünosensörünün 12. haftaya kadar AFP'ye karş1 yanıt verdiğini göstermektedir.
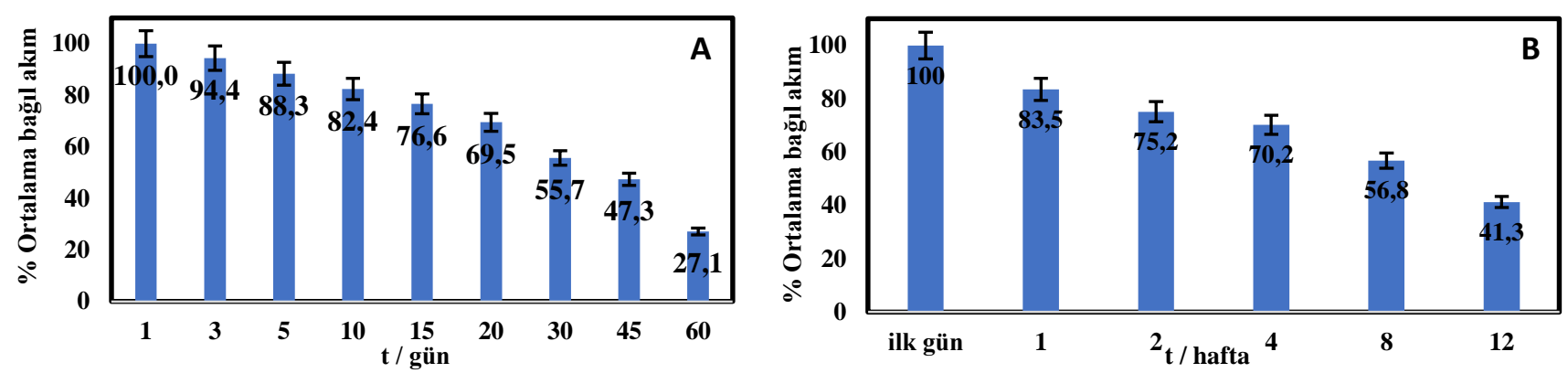

Şekil 7. SPCE/RGO/PNR/AuNP/Anti-AFP/BSA immünosensörünün 50 ng mL ${ }^{-1}$ AFP konsantrasyonuna karşı elde edilen \% ortalama bağıl akım değerlerine karşı (A) gün sayısı grafiği (B) hafta sayısı grafiği

Son yıllarda literatürde çeşitli materyallerle modifiye edilerek AFP'nin tayini için hazırlanmış olan etiketsiz immünosensörler ile bu çalışmada geliştirilmiş olan etiketsiz SPCE/RGO/PNR/AuNP/AntiAFP/BSA/AFP immünosensörünün analitiksel performanslarının karşılaştırılması Çizelge 7'de verilmiştir. Çalışmamızda geliştirdiğimiz AFP immünosensörünün en uzun uygulama kararlılığına sahip olduğu görülmektedir. AFP inkübasyon süresinin ise genel olarak kısa olduğu anlaşılmaktadır. SPCE’lerin pratik, düşük maliyetli ve taşınabilir olması çalışmamızda geliştirdiğimiz etiketsiz AFP 
immünosensörünün, hasta başı testlerde AFP tayininde kullanılmasına imkân sağlayabilir. Sağlıklı insan serumunda, AFP konsantrasyonu genellikle $20 \mu \mathrm{g} \mathrm{mL}^{-1}$ 'den düşükken, karaciğer kanseri hastalarında bu değer $20 \mu \mathrm{g} \mathrm{mL}^{-1}$, den önemli ölçüde fazladır (Wu ve ark., 2019). Literatürde yer alan bu bilgiler 1şı̆̆ında, bu çalışmada geliştirdiğimiz AFP immünosensörünün tayin limit aralığının ve diğer analitiksel parametrelerinin klinik açıdan AFP tespit uygulamalarında yeterli olduğu söylenebilir.

Çizelge 7. Son yıllarda çeşitli materyallerle modifiye edilerek AFP'nin tayini için hazırlanmış olan etiketsiz immünosensörler ile bu çalışmada geliştirilmiş olan etiketsiz AFP immünosensörünün analitiksel performanslarının karşılaştırılması

\begin{tabular}{|c|c|c|c|c|c|c|}
\hline İmmünosensör & $\begin{array}{l}\text { Tayin aralığ } \\
\left(\text { ng } \mathbf{~ L L}^{-1}\right)\end{array}$ & Tespit limiti & Metot & $\begin{array}{c}\text { Stabilite } \\
\text { (gün) }\end{array}$ & $\begin{array}{l}\text { AFP inkübasyon } \\
\text { süresi (dk) }\end{array}$ & Referans \\
\hline$\overline{\text { GCE/CNP/Anti-AFP/BSA/AFP }}$ & $0.005-1000$ & $1.9 \mathrm{pg} \mathrm{mL}^{-1}$ & SWV & - & 40 & Idris ve ark., 2018 \\
\hline GCE/PHEMA/RGO/AuNP/Anti-AFP/BSA/AFP & $0.0025-25$ & $0.40 \mathrm{pg} \mathrm{mL}^{-1}$ & SWV & 15 & 30 & Liang ve ark., 2019 \\
\hline SPCE/RGO/PNR/AuNP/Anti-AFP/BSA/AFP & $1-500$ & $0.89 \mathrm{ng} \mathrm{mL}^{-1}$ & SWV & 60 & 15 & Bu çalışma \\
\hline SPCE/AuNP/RGO/THI/Anti-AFP/BSA/AFP & $100-100000$ & $50 \mathrm{ng} \mathrm{mL}^{-1}$ & DPV & - & 60 & Li ve ark., 2018 \\
\hline GCE/AuNP-Dex-RGO/Anti-AFP/BSA/AFP & $0.01-20$ & $0.05 \mathrm{pg} \mathrm{mL}^{-1}$ & DPV & 28 & 30 & Zhou ve ark., 2019 \\
\hline GCE/Cu H $_{3}$ Pt NF-RGO/Anti-AFP/BSA/AFP & $0.0001-10$ & $0.033 \mathrm{pg} \mathrm{mL}^{-1}$ & DPV & 5 & - & Wang ve ark., 2019 \\
\hline SPCE/RGO/PNR/AuNP/Anti-AFP/BSA/AFP & $1-500$ & $0.79 \mathrm{ng} \mathrm{mL}^{-1}$ & DPV & 60 & 15 & Bu çalışma \\
\hline
\end{tabular}

SPCE: yüzey baskılı karbon elektrot, GCE: camsı karbon elektrot, RGO: indirgenmiş grafen oksit, AuNP: altın nanopartikül, PNR: polinötral kırmızı, THI: tiyonin, CNP: karbon nanopartikül, Dex: dekstran, PHEMA: 2-hidroksietil metakrilat, $\mathrm{Cu}_{3} \mathrm{Pt}$ NF: $\mathrm{Cu}_{3} \mathrm{Pt}$ nano çerçeveler

\section{Seçicilik Testi}

Optimum çalışma şartlarında geliştirilen etiketsiz SPCE/RGO/PNR/AuNP/Anti-AFP/BSA immünosensörünün seçiciliğini belirlemek için her biri $20 \mathrm{ng} \mathrm{mL}^{-1}$ konsantrasyonuna sahip olan on farklı antijen karışımı kullanılarak AFP immünosensörleri hazırlanmıştır. Karışımda yer alan antijenler HE4, CA125, AFP, MAGE1, Haptoglobin, HSP70, PAK2, SOX2, Leptin ve TRAP1'dir. Hazırlanan immünosensörler ile $5 \mathrm{mM}\left[\mathrm{Fe}(\mathrm{CN})_{6}\right]^{-3 /-4}(1 \mathrm{M} \mathrm{KCl})$ çözeltisinde DPV ve SWV ölçümleri yapılmıştır. Voltamogramlardan elde edilen \% ortalama bağıl akım değerlerine karşı AFP ve antijen karışımı grafiği Şekil 8'de verilmiştir. Antijen karışımı varlığında elde edilen \% ortalama bağıl akım değeri sadece AFP varlığında elde edilen değere göre \%4.02 artmıştır. Antijen karışımı varlığında \% ortalama bağıl akım değerindeki bu artışın \%5'in altında olması, SPCE/RGO/PNR/AuNP/Anti-AFP/BSA immünosensörünün seçiciliğinin antijen karışımı varlığında iyi olduğunu göstermektedir.

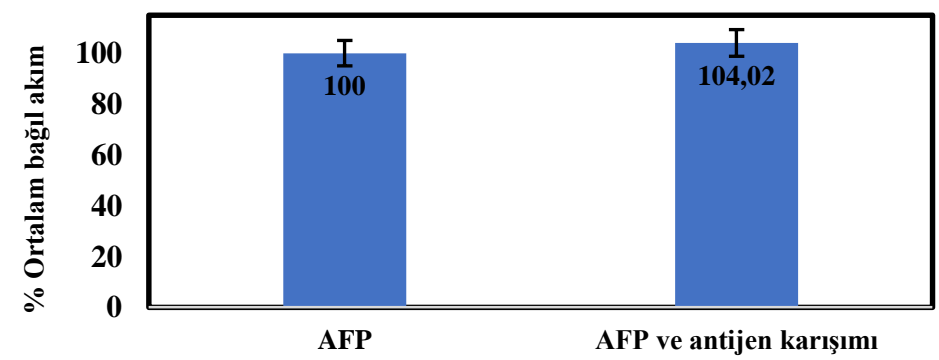

Şekil 8. SPCE/RGO/PNR/AuNP/Anti-AFP/BSA immünosensörünün AFP ve farklı antijenlerin karışımına karşı elde edilen \% ortalama bağıl akım grafiği

\section{Gerçek Numune Analizi}

Geliştirdiğimiz AFP immünosensörleri gerçek numune analizinde kullanılmıştır. Sigma-Aldrich firmasından satın alınan insan serumu numunesi 1:100 oranında $\mathrm{pH} 7.4$ fosfat tampon çözeltisi ile seyreltilmiştir. İnsan serumu numunesine bilinen konsantrasyonlarda AFP ilave edilerek, AFP içeren insan serumu numuneleri hazırlanmıştır. Bilinen miktarda AFP içeren insan serumu numunelerindeki AFP'nin elektrokimyasal tayini SPCE/RGO/PNR/AuNP/Anti-AFP/BSA/AFP immünosensörleri kullanılarak yapılmıştır. İnsan serumu numunelerinde yapılan elektrokimyasal AFP analizinin 
sonuçlarından elde edilen veriler Çizelge 8 'de verilmiştir. Her iki metotta da yüzde hatanın \%5'ten az olduğu ve geri kazanımların \%95'in üstünde olduğu çizelgedeki verilerden görülmektedir. Bu sonuçlara göre, çalışmamızda geliştirdiğimiz etiketsiz AFP immünosensörleri ile insan serumu örneklerinde AFP'nin elektrokimyasal analizi, yüksek \% geri kazanım ve düşük \% hata değerleri ile başarılı bir şekilde yapılmıştır.

Çizelge 8. İnsan serumu numunelerinde AFP analizi

\begin{tabular}{|c|c|c|c|c|}
\hline Metot & Eklenen AFP $\left(\mathrm{ng} \mathrm{mL}^{-1}\right)$ & Hesaplanan AFP $\left(\mathrm{ng} \mathrm{mL}^{-1}\right)$ & \% Geri Kazanım & \% Hata \\
\hline \multirow{3}{*}{ DPV } & 5.0 & $4.86 \pm 0.32$ & 97.2 & 2.8 \\
\hline & 25.0 & $24.15 \pm 0.22$ & 96.6 & 3.4 \\
\hline & 250.0 & $245.18 \pm 0.18$ & 98.1 & 1.9 \\
\hline \multirow{3}{*}{ SWV } & 5.0 & $4.79 \pm 0.34$ & 95.8 & 4.2 \\
\hline & 25.0 & $24.32 \pm 0.26$ & 97.3 & 2.7 \\
\hline & 250.0 & $244.31 \pm 0.16$ & 97.7 & 2.3 \\
\hline
\end{tabular}

\section{SONUÇ}

Karaciğer, testis ve hepetosellular kanseri (HCC) hastalarında AFP seviyelerinin takibi çok önemlidir. $\mathrm{Bu}$ nedenle, bu önemli biyobelirtecin analizini gerçekleştirmek için literatürde birçok biyosensör bulunmaktadır. Bu çalışmada RGO, PNR ve AuNP ile modifiye edilmiş SPCE'ler kullanılarak düşük maliyetli, pratik, tek kullanımlık ve etiketsiz elektrokimyasal AFP immünosensörü geliştirilmiştir. Geliştirilen elektrokimyasal AFP immünosensörü, 1-500 ng mL $\mathrm{m}^{-1}$ konsantrasyon aralığında DPV ve SWV metotları ile sirasıyla $0.79 \mathrm{ng} \mathrm{mL}^{-1}$ ve $0.86 \mathrm{ng} \mathrm{mL}^{-1}$ tespit limitlerinde, iyi tekrarlanabilirlik, yüksek uygulama ve depolama kararlılığı göstermiştir. İnsan serumu numunelerinde geliştirilen AFP immünosensörleri kullanılarak, AFP analizleri yapılmış ve yüksek geri kazanımlar elde edilmiştir. $\mathrm{Bu}$ çalışmada geliştirilen pratik, tek kullanımlık, düşük maliyetli ve etiketsiz AFP immünosensörü AFP'nin klinik analizi için diğer tayin metotlarına göre iyi bir alternatif olabilir ve AFP seviyelerinin takibi için hasta başı testlerde kullanılabilir.

\section{TEŞEKKÜR}

$\mathrm{Bu}$ çalışma, Çankırı Karatekin Üniversitesi Bilimsel Araştırma Projeleri Koordinasyon Birimi tarafindan "FF61218209" kodlu proje ile desteklenmiştir.

\section{Çıkar Çatışması}

Yazarlar tarafından herhangi bir çıkar çatışması veya ortak çıkar beyan edilmemiştir.

\section{Yazar Katkısı}

Bu çalışma Kadir ERDEM'in yüksek lisans tezidir. Araştırma fikri danışman Melike BİLGİ KAMAÇ ve yüksek lisans öğrencisi Kadir Erdem'e aittir. Melike BİLGI KAMAÇ'in çalışmaya destek sağlamada, etiketsiz AFP immünosensörünün hazırlanmasında ve geliştirilmesinde, deneylerin yürütülmesinde, bulguların yorumlanmasında büyük katkıları olmuştur. Kadir ERDEM deneysel çalışmalarda ve yüksek lisans tezinin yazılmasında katkıda bulunmuştur.

\section{KAYNAKLAR}

Altun M, Bilgi Kamaç M, Bilgi A, Yılmaz M, 2020. Dopamine biosensor based on screen-printed electrode modified with reduced graphene oxide, polyneutral red and gold nanoparticle. International Journal of Environmental Analytical Chemistry, 100(4): 451-467. 
Attar A, Ghica ME, Amine A, Brett CM, 2014. Poly (neutral red) based hydrogen peroxide biosensor for chromium determination by inhibition measurements. Journal of hazardous materials, 279: 348-355.

Aydın EB, Sezgintürk MK, 2017. A sensitive and disposable electrochemical immunosensor for detection of SOX2, a biomarker of cancer, Talanta 172: 162-170.

Aydın M, Aydın EB, Sezgintürk MK, 2017. A highly sensitive immunosensor based on ITO thin films covered by a new semi-conductive conjugated polymer for the determination of TNF $\alpha$ in human saliva and serum samples, Biosensors and Bioelectronic 97:169-176.

Bahadır EB, Sezgintürk, MK, 2015. Applications of electrochemical immunosensors for early clinical diagnostics, Talanta, 132: 162-174.

Bilgi Kamac M, Kiymaz Onat E, Yilmaz M, 2020a. A novel non-enzymatic amperometric $\mathrm{H}_{2} \mathrm{O}_{2}$ sensor based on screen-printed electrode modified with reduced graphene oxide, polyneutralred and gold nanoparticles, International Journal of Environmental Analytical Chemistry, 100(4): 408-418.

Bilgi Kamac M, Kiymaz Onat E, Yilmaz M, 2020b. A new disposable amperometric NADH sensor based on screen-printed electrode modified with reduced graphene oxide/polyneutral red/gold nanoparticle, International Journal of Environmental Analytical Chemistry, 100(4): 419-431.

Bilgi M, Ayranci E, 2018. Development of amperometric biosensors using screen-printed carbon electrodes modified with conducting polymer and nanomaterials for the analysis of ethanol, methanol and their mixtures, Journal of Electroanalytical Chemistry, 823: 588-592.

Bilgi M, Ayranc1 E, 2016. Biosensor application of screen-printed carbon electrodes modified with nanomaterials and a conducting polymer: Ethanol biosensors based on alcohol dehydrogenase, Sensors and Actuators B: Chemical, 237: 849-855.

Demirbakan B, Sezgintürk MK, 2020. A novel ultrasensitive immunosensor based on disposable graphite paper electrodes for troponin T detection in cardiovascular disease, Talanta, 213: 120779.

Diaconu I, Cristea C, Harceaga V, Marrazza G, Berindan-Neagoe I, Sandulescu R, 2013. Electrochemical immunosensors in breast and ovarian cancer, Clinica Chimica Acta, 425: 128-138.

Fan F, Shen HY, Zhang GJ, Jiang XY, Kang XX, 2014. Chemiluminescence immunoassay based on microfluidic chips for $\alpha$-fetoprotein, Clinica Chimica Acta, 431: 113-117.

Fang X, Li XQ, Wang H, Wu XM, Wang GL, 2018. Tuning surface states to achieve the modulated fluorescence of carbon dots for probing the activity of alkaline phosphatase and immunoassay of alphafetoprotein, Sensors and Actuators B: Chemical, 257: 620-628.

Fanjul-Bolado P, Queipo P, Lamas-Ardisana PJ, Costa-Garcia A, 2007. Manufacture and evaluation of carbon nanotube modified screen-printed electrodes as electrochemical tools, Talanta, 74: 427-433.

Idris OA, Mabuba N, Arotiba OA, 2018. An alpha-fetoprotein electrochemical immunosensor based on a carbon/gold bi-nanoparticle platform, Analytical Methods, 10: 5649-5658.

Jothi L, Jaganathan SK, Nageswaran G, 2020, An electrodeposited Au nanoparticle/porous graphene nanoribbon composite for electrochemical detection of alpha-fetoprotein, Materials Chemistry and Physics, 242: 122514.

Lan Q, Shen H, Li J, Ren C, Hu X, Yang Z, 2020. Facile synthesis of novel reduced graphene oxide@ polystyrene nanospheres for sensitive label-free electrochemical immunoassay, Chemical Communications, 56(5): 699702.

Li G, Li S, Wang Z, Xue Y, Dong C, Zeng J, Huang Y, Liang J, Zhou Z, 2018. Label-free electrochemical aptasensor for detection of alpha-fetoprotein based on AFP-aptamer and thionin/reduced graphene oxide/gold nanoparticles, Analytical Biochemistry, 547: 37-44.

Liang XL, Bao N, Luo XL, Ding SN, 2018. CdZnTeS quantum dots based electrochemiluminescent image immunoanalysis, Biosensors and Bioelectronics, 117:145-152.

Liang Y, Zhao X, Wang N, Wang J, Chen H, Bai L, Wang W, 2019. A label-free immunosensor based on PHEMA/graphene oxide nanocomposite for simultaneous electrochemical determination of alpha fetoprotein, RSC Advances, 9(30): 17187-17193. 
Liu Q, Yang T, Ye Y, Chen P, Ren X, Rao A, Wan Y, Wang B, Luo Z, 2019. A highly sensitive label-free electrochemical immunosensor based on an aligned GaN nanowires array/polydopamine heterointerface modified with Au nanoparticles, Journal of Materials Chemistry B, 7(9): 1442-1449.

Pauliukaite R, Brett CM, 2008. Poly (neutral red): Electrosynthesis, characterization, and application as a redox mediator. Electroanalysis: An International Journal Devoted to Fundamental and Practical Aspects of Electroanalysis, 20(12): 1275-1285.

Preechakasedkit P, Siangproh W, Khongchareonporn N, Ngamrojanavanich N, Chailapakul O, 2018. Development of an automated wax-printed paper-based lateral flow device for alpha-fetoprotein enzymelinked immunosorbent assay, Biosensors and Bioelectronics, 102:27-32.

Putzbach W, Ronkainen, NJ, 2013. Immobilization Techniques in the Fabrication of Nanomaterial-Based Electrochemical Biosensors: A Review, Sensors 13: 4811-4840.

Sezgintürk MK, 2011. A new impedimetric biosensor utilizing vegf receptor-1 (flt-1): Early diagnosis of vascular endothelial growth factor in breast cancer, Biosensors and Bioelectronics, 26:10, 4032-4039.

Sonuç Karaboğa MN, Sezgintürk MK, 2019. Cerebrospinal fluid levels of alpha-synuclein measured using a polyglutamic acid-modified gold nanoparticle-doped disposable neurobiosensor system, Analyst 144: 611-621.

Şahin M, Ayranc1 E, 2015. Electrooxidation of NADH on modified screen-printed electrodes: effects of conducting polymer and nanomaterials, Electrochimica Acta, 166: 261-270.

Tang Z, Ma Z, 2017. Multiple functional strategies for amplifying sensitivity of amperometric immunoassay for tumor markers: A review, Biosensors and Bioelectronics, 98: 100-12.

Tudorache M, Bala C, 2007. Biosensors based on screen-printing technology, and their applications in environmental and food analysis", Analytical and Bioanalytical Chemistry, 388: 565-578.

Wang AJ, Zhu XY, Chen Y, Yuan PX, Luo X, Feng JJ, 2019. A label-free electrochemical immunosensor based on rhombic dodecahedral $\mathrm{Cu}_{3} \mathrm{Pt}$ nanoframes with advanced oxygen reduction performance for highly sensitive alpha-fetoprotein detection, Sensors and Actuators: B. Chemical 288: 721-727.

Wangkam T, Boonperm K, Khomkrachang P, Srikhirin T, Praphanphoj V, Sutapan B, Somboonkaew A, Amarit R, 2016. Hepatocellular carcinoma biomarker detection by surface plasmon resonance sensor, In Advanced Materials Research, 1131: 84-87.

Wu Y, Wang Y, Wang X, Wang C, Li C, Wang Z, 2019. Electrochemical Sensing of $\alpha$-Fetoprotein Based on Molecularly Imprinted Polymerized Ionic Liquid Film on a Gold Nanoparticle Modified Electrode Surface, Sensors, 19(14): 3218.

Yang SH, Zhang FF, Wang ZH, Liang QL, 2018. A graphene oxide-based label-free electrochemical aptasensor for the detection of alpha-fetoprotein, Biosensors and Bioelectronics, 112:186-192.

Yuan X, Longa W, Liu J, Zhang B, Zhou W, Jiang J, Yu B, Wang H, 2019. Associations of serum markers screening for Down's syndrome with pregnancy outcomes: A Chinese retrospective cohort study, Clinica Chimica Acta, 489:130-135.

Zhou J, Zhang C, Chen Y, Wang Z, Lan L, Wang Y, Han B, Pan M, Jiao J, Chen Q, 2019. A simple immunosensor for alpha-fetoprotein determination based on gold nanoparticles-dextran-reduced graphene oxide, Journal of Electroanalytical Chemistry, 833: 126-132.

Zhou Q, Xue H, Zhang Y, Lv Y, Li H, Liu S, Shen Y, Zhang Y, 2018. Metal-free all-carbon nanohybrid for ultrasensitive photoelectrochemical immunosensing of alpha-fetoprotein, ACS Sensors, 3(7):1385-1391. 